\title{
DIE VERBAND TUSSEN PRESTASIEMOTIVERING EN PRESTASIE AAN 'N BESTUURSBEOORDELINGSENTRUM
}

\section{STROEBEL *}

AFDELING MANNEKRAG

SUID-AFRIKAANSE VERVOERDIENSTE
I. VAN W. RAUBENHEIMER

DEPARTEMENT BEDRYFSIELKUNDE

RANDSE AFRIKAANSE UNIVERSITEIT

\section{SUMMARY}

A survey of the literature indicates that the traditional selection methods, i.e. psychometric predictors, have up to date not been very successful in the identification of future leaders. The Assessment Centre is a technique that has in recent years been applied worldwide as an alternative method. Although scientifically justifiable, it is very costly and time consuming. In order to find a method of pre-selection to the assessment centre it is hypothesised that there is a significant positive correlation between achievement motivation and an individual's achievement at an assessment centre.

A significant correlation $(p<, 01)$ is reported between achievement motivation and tenacity as well as planning and organising. Results further indicate a significant correlation between the sum of the dimensions evaluated and achievement motivation.

Die doeltreffende voortbestaan van meeste ondernemings hang ten nouste saam met die effektiwiteit van hul bestuurskorps. Dit is derhalwe van uiterste belang dat individue met goeie leierspotensiaal vroegtydig geïdentifiseer word sodat slegs die beste persone na hoër bestuursposte vorder. 'n Oorsig van die literatuur dui daarop dat die tradisionele keuringstegnieke (Psigometriese voorspelling) tot op hede nie besonder geslaagd was om toekomstige leiers te identifiseer nie (Korman, 1968).

'n Tegniek wat in die jongste tyd al hoe meer veld wen wat die identifisering van persone met bestuurspotensiaal betref en ook redelik intensief in Suid-Afrika toegepas word, is bestuursbeoordelingsentrums, ook genoem takseersentrums (Loubser, 1976). Alhoewel die voorspellingsgeldigheid van takseersentrums reeds in ' $n$ afdoende mate aangedui is, is die aantal persone wat op 'n gegewe tydstip beoordeel kan word, beperk. Verder kry baie jong werknemers nie gou genoeg die geleentheid om 'n takseersentrum by te woon nie, omdat

\footnotetext{
* Versoeke vir afskrifte moet aan die eerste skrywer gerig word.
} 
persone normaalweg op grond van senioriteit 'n sentrum bywoon (Moses, 1973). Die feit dat takseersentrums 'n koste- sowel as tydsintensiewe tegniek is, noodsaak dat daar gekyk word of persone wat waarskynlik goed aan so 'n sentrum sal vaar, vroegtydig geïdentifiseer kan word.

Uit die literatuur oor motiveringsteorieë is dit duidelik dat geen persoon besonder goed in dit wat hy doen sal presteer indien hy nie gemotiveer is om sy beste te lewer nie (Porter, Lawler en Hackman, 1975). Daar kan dus met reg gevra word of persone wat takseersentrums bywoon gemotiveerd is om goed te presteer.

Hierdie studie is onderneem met die doel om te bepaal of persone wat oor 'n hoë vlak van prestasiemotivering beskik, goed aan 'n takseersentrum sal vaar. Deur vas te stel of daar 'n positiewe verband tussen die twee veranderlikes bestaan kan bepaalde afleidings gemaak word rakende die preseleksie van persone wat 'n takseersentrum moet bywoon.

\section{METODE}

\section{Hipotese}

Die volgende hipotese is vir hierdie studie gestel: Daar bestaan 'n beduidende positiewe verband tussen prestasiemotivering en prestasie aan 'n bestuursbeoordelingsentrum.

\section{Meetmiddels}

Ten einde die hipotese te toets, was twee tellings nodig:

- $\quad$ die individu se takseersentrumresultate, en

- $\quad$ die individu se prestasiemotiveringresultate.

Takseersentrumresultate was beskikbaar ten opsigte van persone wat reeds 'n takseersentrum bygewoon het. Tydens sodanige sentrum word persone op 13 verskillende bestuursdimensies beoordeel.

Prestasiemotivering is gemeet deur die volgende vraelyste in beide ampstale aan die 600 persone te stuur:

- die Mehrabian Resultant Achievement Motive skaal (RAM)

- $\quad$ die Ray-Lynn vraelys (A.O.)

- die Prestasiemotiveringsvraelys van Pottas et al. (1980) (PMV). 
Die onderliggende uitgangspunt van die RAM is dat hoë presteerders se motivering om te presteer sterker as hul vrees vir mislukking is terwyl lae presteerders se vrees vir mislukking sterker is as hul motivering om te presteer. Daar is besluit om hierdie vraelyste te gebruik as gevolg van die goeie resultate wat met hierdie meetinstrument verkry is (Mehrabian, 1969).

Die Ray-Lynn AO-skaal bestaan uit 14 items en is volgens Ray (1979) reeds in Engeland, Australië en Suid-Afrika as geldig en betroubaar bevind.

Die PMV is ontwikkel om die sterkte motivering om te presteer by volwassenes te meet. Meting geskied deur middel van gedwonge keuse items. In die konstruksie van die vraelys is ' $\mathrm{n}$ faktoranalitiese benadering gevolg ten einde te verseker dat die konstruk prestasiemotivering so suiwer as moontlik gemeet word (Pottas et al., 1980).

\section{Die Monster}

Die 600 proefpersone wat by hierdie studie betrek is, is almal werksaam binne die vervoerorganisasie waarbinne die studie uitgevoer is. Almal beklee bestuursposte en het reeds 'n takseersentrum bygewoon. Die proefgroep het bestaan uit slegs mans en hul werkplekke is geografies oor die Republiek van Suid-Afrika versprei. 'n Redelike verskil bestaan tussen die ouderdom, opvoedkundige kwalifikasies en werkskennis van die proefpersone. Die groep bestaande uit Afrikaans- sowel as Engelssprekende persone, is gevra om op 'n gewillige grondslag deel te neem.

\section{Strategie}

Driehonderd vraelyste is terugontvang waarvan 17 bederf was. Die oorblywende 283 is op ewekansige wyse in twee groepe verdeel, $\mathrm{nr}$. 'n proefgroep $(\mathrm{N}=200)$ en 'n kruisvalidasiegroep $(\mathrm{N}=83)$. Hierna is die prestasiemotiveringspunt van elke individu in die proefgroep met die dertien beoordelingsdimensies gekorreleer. 'n Regressievergelyking is vir die proefgroep bepaal en aan die hand hiervan is voorspelde takseerdimensiepunte vir die kruisvalidasiegroep bereken. Dié voorspelde punt is met die ware takseerdimensiepunt vir dié groep gekorreleer.

Ten einde die beste moontlike voorspelbaarheid te probeer vind, is beoordelingdimensiepunte hierna gesommeer en is dieselfde prosedure soos hierbo gevolg.

Tabel 1 is ' $n$ weergawe van die interkorrelasies gevind tussen die drie vraelyste. 
$\underline{\text { TABEL } 1}$

INTERKORRELASIES TUSSEN PMW, AO EN RAM

\begin{tabular}{|l|c|c|c|}
\hline VRAELYSTE & PMV & AO & RAM \\
\hline PMW & 1,0 &, $55^{*}$ &, $49^{*}$ \\
AO & & 1,0 &, $29^{*}$ \\
RAM & & & 1,0 \\
\hline
\end{tabular}
* $<, 01$

Alhoewel al drie vraelyste beduidend met mekaar op die $1 \%$ vlak korreleer, is geeneen van die korrelasiekoëffisiënte besonder hoog nie. Die hoogste korrelasie is tussen PMV en $\mathrm{AO}(0,55)$.

Om die data behoorlik te benut is daar besluit om die drie prestasiemotiveringspunte te kombineer. Hierdie prestasiemotiveringsvoorspellers is met die dertien beoordelingsdimensies vir die proefgroep gekorreleer. Die meervoudige korrelasiekoëffisiënte word in Tabel 2 uiteengesit.

Beduidende korrelasies op die $1 \%$ peil is gevind tussen die drie prestasiemotiveringsvoorspellers en selfontwikkeling, inisiatief, deursettingsvermoë en redeneringsvermoë terwyl 'n beduidende korrelasie op die $5 \%$ vlak gevind is met beplanning en organisering. Geeneen van hierdie korrelasiekoëffisiënte is egter besonder hoog nie.

\section{$\underline{\text { TABEL } 2}$}

MEERVOUDIGE KORRELASIE TUSSEN PRESTASIEMOTIVERINGSVOORSPELLER EN DIMENSIES VAN DIE TAKSEERSENTRUM

\begin{tabular}{|l|c|}
\hline \multicolumn{1}{|c|}{ BEOORDELINGSDIMENSIES } & $\begin{array}{c}\text { KORRELASIE- } \\
\text { KOËFFISIËNT }\end{array}$ \\
\hline SELFONTWIKKELING &, $32^{* *}$ \\
INISIATIEF &, $25^{* *}$ \\
DEURSETTINGSVERMOË &, $30^{* *}$ \\
ANALITIESE VERMOË &, 12 \\
OORDEELSVERMOË &, 10 \\
BUIGSAAMHEID &, 08 \\
MENSBENUTTING &, 19 \\
BESLISTHEID &, 14 \\
TAAKSTRUKTURERING &, 22 \\
EMPATIE &, 14 \\
REDENERINGSVERMOË &, $29^{* *}$ \\
AANBIEDINGSVERMOË &, 17 \\
BEPLANNING \& ORGANISERING &, $21^{*}$ \\
$* \mathrm{p}<, 05$ & \\
$* * \mathrm{p}<, 01$ &
\end{tabular}


Heelwat van hierdie korrelasies stem ooreen met vorige navorsingsbevindinge. So byvoorbeeld het Mehrabian (1968) gevind dat hoë presteerders geneig is tot volharding terwyl daar in hierdie studie ' $n$ beduidende korrelasie $(, 30)$ met deursettingsvermoë gevind is. Morris en Fargher (1974) het gevind dat prestasiegemotiveerde persone vindingryk te werk gaan en dus oor 'n hoë mate van inisiatief beskik. Die beduidende korrelasie $(, 25)$ wat in hierdie studie gevind is, is in orreenstemming met hul bevinding. Die beduidende korrelasie met beplanning en organisering $(, 21)$ stem ook ooreen met McClelland (1969) se bevindings dat hoë presteerders vooruit beplan. McClelland het ook gevind dat hoë presteerders nie noodwendig oor 'n hoër intelligensie as lae presteerders beskik nie. In hierdie studie was die korrelasie met analitiese vermoë glad nie beduidend nie $(, 12)$.

Vanuit die meervoudige korrelasiekoëffisiënte (Tabel 2) het dit reeds geblyk dat dit moeilik sou wees om toekomstige prestasie van individue met groot sukses aan 'n takseersentrum te voorspel. Daar is egter nietemin besluit om ter wille van die volledigheid van die studie voort te gaan met die kruisvalidasiestudie ten opsigte van dié dimensies wat beduidend gekorreleer het.

Met behulp van regressiegewigte, soos bereken vir die proefgroep, is elke persoon in die kruisvalidasiegroep se voorspelde dimensiepunt bereken. Hierdie berekende punt is gekorreleer met die individu se werklike punt soos behaal aan 'n takseersentrum. Dié koëffisiënte word in Tabel 3 uiteengesit.

$\underline{\text { TABEL } 3}$

\section{KORRELASIE TUSSEN PRESTASIEMOTIVERINGSVOORSPELLERS EN BEOORDELINGSDIMENSIES VIR KRUISVALIDASIEGROEP}

\begin{tabular}{|c|c|c|}
\hline DIMENSIES & $\begin{array}{c}\text { PROEFGROEP } \\
\text { R }\end{array}$ & $\begin{array}{c}\text { KRUISVALIDASIE- } \\
\text { GROEP r }\end{array}$ \\
\hline SELFONTWIKKELING &, $32 * *$ & ,21 \\
\hline INISIATIEF & $25 * *$ & 18 \\
\hline DEURSETTINGSVERMOË & ,30** &, $30 * *$ \\
\hline REDENERINGSVERMOË &, $29 * *$ & ,16 \\
\hline BEPLANNING \& ORGANISERING &, $21 *$ &, $33 * *$ \\
\hline
\end{tabular}

Uit Tabel 3 kan afgelei word dat deursettingsvermoë en beplanning en organisering beduidend op die $1 \%$ peil met die prestasiemotiveringsvoorspeller korreleer. Dié koëffisiënte $(, 30$ en, 33$)$ is nie besonder hoog nie en verklaar slegs ongeveer $10 \%$ van die gemeenskaplike 
variansie. 'n Individu se prestasie ten opsigte van die twee beoordelingsdimensies kan dus nie met groot sukses in groepe anders as die proefgroep voorspel word nie.

Wat die gesommeerde beoordelingsdimensiepunte betref is 'n korrelasie van ,27 met die prestasiemotiveringsvoorspellers vir die proefgroep gevind wat beduidend is op die $5 \%$ peil. 'n Korrelasiekoëffisiënt van ,33 (op die $1 \%$ peil) is vir die kruisvalidasiegroep gevind.

Die resultate van hierdie studie toon aan dat daar waarskynlik nog steeds probleme rondom die omskrywing van die begrip prestasiemotivering bestaan. Die feit dat daar nie 'n besonder bemoedigende interkorrelasie tussen die drie prestasiemotiveringsvraelyste verkry is nie, dui moontlik daarop dat dit nie dieselfde konstruk meet nie. Dit wil nietemin voorkom asof die PMV van Pottas die beste korrelasie met prestasie tydens 'n takseersentrum toon.

Dit blyk ook dat die drie vraelyste soos in hierdie studie gebruik is, nie met groot sukses aangewend kan word om 'n individu se prestasie volgens bestuursdimensies tydens ' $n$ takseersentrum te voorspel nie.

Dit blyk egter dat daar met behulp van die voorspellerdata met 'n redelike mate van sukses voorspel kan word of ' $n$ individu in die geheel gesien, goed of swak behoort te vaar.

\section{OPSOMMING}

'n Oorsig van die literatuur dui daarop dat die tradisionele keuringsmetodes, dit is psigometriese voorspellers, tot datum nie baie suksesvol was in die identifisering van toekomstige leiers nie. Die takseersentrum is 'n tegniek wat in resente jare wêreldwyd as alternatiewe metode aangewend is. Alhoewel dit wetenskaplik verantwoordbaar is, is dit tyd-en koste intensief. In 'n soeke na 'n vorm van preseleksie word die hipotese gestel dat daar ' $n$ beduidende positiewe verband tussen prestasiemotivering en prestasie aan 'n takseersentrum bestaan. 'n Beduidende korrelasie ( $p<, 01)$ word gerapporteer tussen prestasiemotivering en deursettingsvermoë en beplanning en organisering. Resultate dui ook op 'n beduidende korrelasie tussen die somtotaal van beoordelingsdimensies en prestasiemotivering.

\section{VERWYSINGS}

Korman, A.K. The prediction of managerial performance: A review. Personnel Psychology, 1968, 21, 295-322.

Loubscher, K. Management selection and training : SAR's new breed of young men. People and Profits, 1976, 6-8.

McClelland, D.C. The Achieving Society. New York: Irvington Publishers, 1967. 
Mehrabian, A. Male and female scales of the tendency to achieve. Educational and Psychological Measurement. 1968, 28, 493-502.

Mehrabian, A. Measures of achieving tendency. Educational and Psychological Measurement, 1969, 29, 445-451.

Morris, J.L. \& Fargher, K. Achievement drive and creativity as correlates of success in small business. Australian Journal of Psychology, 1974, 26(3), 217-222.

Moses, J.L. The development of an assessment center for the early identification of supercisory potential. Personnel Psychology, 1973, 26, 569-580.

Porter, W.P., Lawler, E.E. \& Hackman, J.R. Behavior in Organizations. Tokyo : McGrawHill, 1975.

Pottas, C.D., Erwee, R., Boshoff, A.B. \& Lessing, B.C. Handleiding vir die Prestasiemotiveringsvraelys. Eenheid vir Entrepreneurskap, Universiteit van Pretoria, 1980.

Ray, J.J. A quick measure of achievement motivation - validated in Australia and reliable in Britain and South Africa. Australian Psychologist, 1979, 14(3), 337-344. 